\title{
Characterization of glass beads from Nanhai I shipwreck and new evidence of lead tin yellow type II in China
}

\author{
Chenxin Tian', Yihang Zhou', Kai Wang ${ }^{1 *} \mathbb{0}$, Jian Sun², Yong Cui ${ }^{3}$ and Dongbo Hu ${ }^{1}$
}

\begin{abstract}
Glass beads excavated from Nanhai I shipwreck were investigated with scanning electron microscopy with energy dispersive spectrometer (SEM-EDS), Raman spectroscopy, multi-collector inductively coupled plasma mass spectrometry (MC-ICP-MS) and X-ray diffraction (XRD). Dating back to the Southern Song Dynasty, these beads help to study Chinese maritime trades during the twelfth-thirteenth century. The bead samples are categorized into five groups by color, i.e., yellow, orange-red, blue, dark red and light red. All beads are of $\mathrm{K}_{2} \mathrm{O}-\mathrm{PbO}-\mathrm{SiO}_{2}$ and $\mathrm{PbO}-\mathrm{SiO}_{2}$ glass systems and in form of coil bead, which further confirms the Chinese origin of them. Lead tin yellow type II was identified in the opaque yellow coil beads, and $\mathrm{K}_{2} \mathrm{Sn}_{x} \mathrm{~Pb}_{(1-x)} \mathrm{Si}_{3} \mathrm{O}_{9}$ crystals were found in both yellow and orange-red samples. Through the preparation of glass with the same formula as the ancient yellow beads, lead tin yellow type II was probably synthesized beforehand and added as colorant because its raw materials tend to form $\mathrm{K}_{2} \mathrm{Sn}_{\mathbf{x}} \mathrm{Pb}_{(1-x)} \mathrm{Si}_{3} \mathrm{O}_{9}$ crystals in the $\mathrm{K}_{2} \mathrm{O}-\mathrm{PbO}-\mathrm{SiO}_{2}$ glass during firing. As lead tin yellow type II is an atypical colorant in China, these beads from Nanhai I shipwreck may serve as the first clear evidence of lead tin yellow type II presenting in the Chinese glass system. The lead isotope ratios of the yellow beads suggest they were produced in Fujian Province, China. The introduction of the lead tin yellow coloring technique might have a close connection to the glass making in the Southeast Asia and these beads seemed to be made specifically for overseas markets.
\end{abstract}

Keywords: Nanhai I shipwreck, Lead tin yellow type II, Chinese glass bead, Coil bead

\section{Introduction and research aim}

Chinese glass beads played an important role in the world's bead trades during the twelfth-fourteenth century. However, there is only sketchy information about them. Coil beads are the most common and most widely distributed kind of Chinese glass beads [1]. They are a special kind of wound beads, produced by winding molten glass around a mandrel to form a loop or occasionally several paratactic loops just like coils. Because of these unique features, they were also called "single wound" [2]. They are smaller, shinier and heavier

\footnotetext{
${ }^{*}$ Correspondence: wangkai2004@pku.edu.cn

${ }^{1}$ School of Archaeology and Museology, Peking University, 5 Yiheyuan Road, Beijing 100871, China

Full list of author information is available at the end of the article
}

compared with Indo-Pacific beads, and took the leading position in the Southeast Asian bead market as IndoPacific beads were in decline during the twelfth century $[1,3]$. Coil beads have been excavated from the sites in Southeast Asian countries regularly, and occasionally in East African countries. In the Philippines, Sumatra, East Java of Indonesian, Sarawak of Malaysia and Singapore, coil beads appear in sites after the first millennium, and in sites dated twelfth-fourteenth century A.D. they always dominated $[1,4]$.

Scholars deduced from the technical features and distribution of coil beads that they have a Chinese origin [1, 5-7]. The perspective is convincing, but there is still a lack of direct evidence of manufacturing which is necessary to identify coil beads as Chinese products with certainty. Fortunately, some coil beads have been excavated 
from Nanhai I shipwreck, a cargo ship dating back to the Southern Song Dynasty (1127-1279 A.D.), heading Southeast Asia but sank $20 \mathrm{~km}$ south off the shore of Yangjiang city, Guangdong province. Thousands of pieces of goods have been excavated from this shipwreck. Porcelains and metal wares make up the majority of the cargo [8]. Glass beads were just one of the many kinds of merchandise that the Chinese produced and sold them abroad to pay for the Annual Tribute and increase import needs. Zhu Fan Zhi (诸蕃志) was a guide book of the Southern Song Dynasty for merchants to view what items were in demand by different Southeast Asian areas. "Liuli beads", the archaic expression of glass beads, "Colored fired beads" and "colored liuli beads" were mentioned in Zhu Fan Zhi in the listings of commodities that were traded with local people in Mayi (the islands of Mindoro and Luzon in the Philippines) and Boni (Kalimantan), which corresponds with the distribution of excavated coil beads.

The glass beads samples in this paper are all identified as coil beads. The results of the tests show their high lead contents, consistent with most of the coil beads analyzed $[1,3,5,9]$. Additionally, this is the first time that lead tin yellow is found in Chinese lead glass system. Lead tin yellow glass was produced in Europe during a short period of the first to second century B.C., and the production resumed from first century A.D. This type of glass is a dominant one during the fifth to seventh century at 10 sites around western Europe [10]. As a pigment, lead tin yellow is discovered on paintings from about the fourteenth to eighteenth century in Europe [11-13]. But lead tin yellow is not a common colorant or pigment in Chinese tradition. Glass beads with lead tin yellow type II have been reported in China, but their chemical compositions indicate that they were imported from West or Central Asia [7, 14, 15]. In the glass beads from Nanhai shipwreck I, lead tin yellow type II present itself in the Chinese glass system for the first time. In this paper, the coil bead samples from Nanhai I are examined by scanning electron microscopy with energy dispersive spectrometer, Raman spectroscopy, multi-collector inductively coupled plasma mass spectrometry and X-ray diffraction, in hope that their close and direct relationship with China provides opportunities to look into the maritime glass beads of China during the Southern Song Dynasty. More importantly, the research is more focused on the characterization and technical aspects of the beads containing lead tin yellow type II.

\section{Materials and methods} Materials and classifications

Glass beads were collected by sieving the sludge on site during the excavation of the Nanhai I shipwreck and the samples in this paper were provided by the archaeological staff there. They are all identified as coil beads by their typical coil-like appearance. Based on the surface colors, the glass beads seem to include 9 kinds (Fig. 1a, c, e, h, $\mathrm{i}, \mathrm{k}, \mathrm{m}-\mathrm{o})$. However, after polishing and exposing their inner sections, there are only five colors, i.e., yellow (or lemon-yellow), orange-red, blue, light red, and dark red. Among them, yellow beads and orange-red beads are opaque, light red beads and blue beads are transparent and dark red beads are translucent. Additionally, there are also larger yellow beads about $4 \mathrm{~mm}$ in diameter (shown in Fig. 1g), compared to smaller beads in the other figures about $2 \mathrm{~mm}$ in diameter. Possibly due to certain technical flaws, some beads were not separated and in the form of twin or triplet with evident coil-like signature.

\section{Scanning electron microscopy}

Backscattered electron (BSE) images and chemical compositions of the glass beads were acquired by Hitachi TM3030 scanning electron microscope with energy dispersive spectroscopy (SEM-EDS). EDS analysis was carried out on the cross-sections of each glass bead within an area of over $100 \mu \mathrm{m} \times 100 \mu \mathrm{m}$ and over $60 \mathrm{~s}$ accumulation time under low vacuum mode. Due to the limited sample quantities and their preservation status, typical (judged by cross-section morphology) samples of each kind were tested and mean compositions were calculated. EDS spot tests were carried out on the phases of interest under the same conditions.

\section{Raman spectroscopy}

Raman spectra were acquired by BWTEK i-Raman PLUS with BAC151 Raman video microscope to identify the phases of colorants in glass beads. The detectable spectral range (Raman shift) of the instrument is from 150 to $4200 \mathrm{~cm}^{-1}$ with a resolution of $4.5 \mathrm{~cm}^{-1}$. The laser beam spot size is $105 \mu \mathrm{m}$ under the $20 \mathrm{X}$ objective. The accumulation time in each acquisition was $60 \mathrm{~s}$ under maximum intensity of $532 \mathrm{~nm}$ laser light source $(40 \mathrm{~mW})$.

\section{X-ray diffraction}

XRD analysis was performed on X-pert3 Powder, PANalytical with $\mathrm{Cu}$ anode to detect the crystals in the grinded sample. The working voltage of X-ray tube was $40 \mathrm{kV}$. The working electric current was $40 \mathrm{~mA}$. The scanning degree $2 \theta$ is from $10^{\circ}$ to $80^{\circ}$ with step size $0.013^{\circ}$ and scan step time $53.3 \mathrm{~s}$.

\section{Multi-collector inductively coupled plasma mass spectrometry}

Lead isotope ratios were tested by VG Axiom multi-collector inductively coupled plasma mass spectrometry 


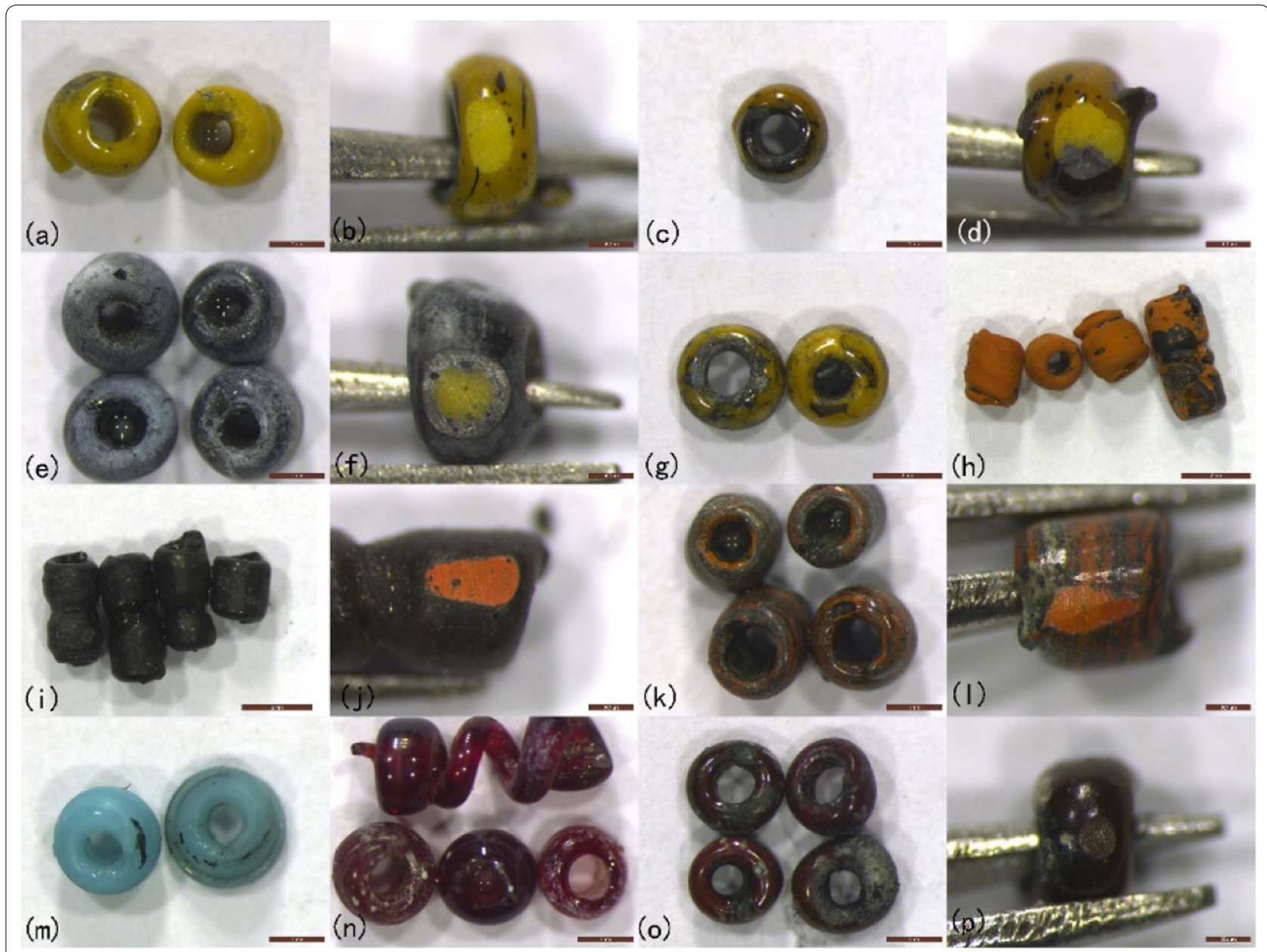

Fig. 1 Appearance of the Nanhai I shipwreck bead samples: yellow beads $(\mathbf{a}-\mathbf{g})$, orange-red beads $(\mathbf{h}-\mathbf{I})$, blue beads $(\mathbf{m})$, light red beads $(\mathbf{n})$, dark red beads (o, p), scale bar $0.5 \mathrm{~mm}(\mathbf{b}, \mathbf{d}, \mathbf{f}, \mathbf{j}, \mathbf{l}, \mathbf{p}), 1 \mathrm{~mm}(\mathbf{a}, \mathbf{c}, \mathbf{e}, \mathbf{f}, \mathbf{k}, \mathbf{m}-\mathbf{o})$, and $2 \mathrm{~mm}(\mathbf{g}-\mathbf{i})$

(MC-ICP-MS). The samples were dissolved in aqua regia, diluted and added $0.5 \mathrm{mg} / \mathrm{L} \mathrm{Tl}_{2} \mathrm{SO}_{4}$ for an internal correction of mass bias. The errors are of $<0.05 \%$ for ${ }^{207} \mathrm{~Pb} /{ }^{206} \mathrm{~Pb}$ and ${ }^{208} \mathrm{~Pb} /{ }^{206} \mathrm{~Pb}$ values.

\section{Simulation of the yellow glass}

Lead tin yellow type II $\left(\mathrm{PbSn}_{\mathrm{x}} \mathrm{Si}_{(1-\mathrm{x})} \mathrm{O}_{3}, \mathrm{~Pb}: \mathrm{Sn}\right.$ :Si feed ratio 2:1:1) was synthesized at $900{ }^{\circ} \mathrm{C}$ for $5 \mathrm{~h}$ with reference to the literatures $[13,16]$ and the glass was fired at $800{ }^{\circ} \mathrm{C}$, $850^{\circ} \mathrm{C}$ and $900{ }^{\circ} \mathrm{C}$ respectively according to the compositions tested. $\mathrm{K}_{2} \mathrm{CO}_{3}$ (AR, from Tianjin Zhiyuan Chemical Reagent Co. Ltd.), $\mathrm{SiO}_{2}$ (silica gel, from Beijing Ocean Chemical Engineering Co. Ltd.), $\mathrm{Pb}_{3} \mathrm{O}_{4}$ (AR, from Sinopharm Chemical Reagent Co. Ltd.) and $\mathrm{SnO}_{2}$ (Shanghai Zhanyun Chemical Co. Ltd.) were used as the raw materials and the firing process took place in a quartz boat with platinum lining heated by an electric tube furnace.

\section{Results and discussion}

The chemical compositions of all bead samples tested are summarized in Table 1 . The Chinese origin of the beads is confirmed with the average $\mathrm{PbO}$ content between 46 and 63 w\% with the secondary fluxing agent as $\mathrm{K}_{2} \mathrm{O}$, which exactly match the chemical features of $\mathrm{K}_{2} \mathrm{O}-\mathrm{PbO}-\mathrm{SiO}_{2}$ and $\mathrm{PbO}-\mathrm{SiO}_{2}$ glass systems of the Song Dynasty [7]. As tin serves as not only colorant but opacifier as well, the yellow and orange-red beads that contain tin oxide are opaque, while blue and light red beads are transparent and dark red beads are translucent.

In SEM images, the vitreous matrices of the beads have distinct particles dispersing within them. The occurrences of these phases vary among different beads. Some of them are euhedral, showing angular edges, and others are rounded or spherical. 
Table 1 Chemical compositions of Nanhai I shipwreck beads (w\%)

\begin{tabular}{|c|c|c|c|c|c|c|c|c|c|c|}
\hline & $\mathrm{PbO}$ & $\mathrm{SiO}_{2}$ & $\mathrm{SnO}_{2}$ & $\mathrm{~K}_{2} \mathrm{O}$ & $\mathrm{Na}_{2} \mathrm{O}$ & $\mathrm{Al}_{2} \mathrm{O}_{3}$ & $\mathrm{MgO}$ & $\mathrm{CaO}$ & $\begin{array}{l}\mathrm{CuO} \text { (blue beads)/ } \\
\mathrm{Cu}_{2} \mathrm{O} \text { (red beads) }\end{array}$ & $\mathrm{Fe}_{2} \mathrm{O}_{3}$ \\
\hline Small opaque Yellow beads $(n=5)$ & 59.14 & 32.40 & 4.38 & 3.66 & 0.23 & 0.19 & - & - & - & - \\
\hline SD & 1.94 & 1.67 & 0.47 & 0.56 & 0.21 & 0.13 & - & - & - & - \\
\hline Large opaque Yellow beads $(n=5)$ & 57.38 & 34.72 & 3.12 & 4.27 & 0.34 & 0.16 & - & - & - & - \\
\hline SD & 2.03 & 1.92 & 0.30 & 0.20 & 0.15 & 0.09 & - & - & - & - \\
\hline Opaque orange-red beads $(n=8)$ & 46.37 & 32.62 & 1.39 & 8.40 & 0.26 & 0.47 & 0.08 & 0.48 & 9.40 & 0.54 \\
\hline SD & 1.06 & 1.21 & 0.46 & 0.75 & 0.29 & 0.32 & 0.11 & 0.36 & 1.50 & 0.22 \\
\hline $\begin{array}{l}\text { Transparent blue beads } \\
(n=2)\end{array}$ & 45.51 & 40.47 & - & 8.34 & 0.77 & 0.44 & 0.24 & 3.34 & 0.75 & 0.16 \\
\hline SD & 0.06 & 0.41 & - & 0.05 & 0.11 & 0.05 & 0.04 & 0.24 & 0.01 & 0.16 \\
\hline Transparent light red beads $(n=6)$ & 51.23 & 39.34 & - & 7.17 & 1.16 & 0.25 & 0.08 & 0.03 & 0.55 & 0.20 \\
\hline SD & 2.30 & 1.67 & - & 1.05 & 0.53 & 0.13 & 0.08 & 0.04 & 0.17 & 0.08 \\
\hline Translucent Dark red beads $(n=4)$ & 63.44 & 32.36 & - & 0.47 & - & 0.22 & - & 0.45 & 1.64 & 1.42 \\
\hline SD & 1.14 & 1.13 & - & 0.03 & - & 0.10 & - & 0.06 & 0.10 & 0.10 \\
\hline
\end{tabular}

\section{Yellow beads}

For yellow beads, both lighter and darker phases present themselves in the BSE images, representing phases of higher average atomic number than that of the matrix and those of lower average atomic number. The dark particles with sharp edges in Figs. $2 \mathrm{a}$ and $3 \mathrm{~b}$ are featured with high contents of $\mathrm{K}_{2} \mathrm{O}, \mathrm{SnO}_{2}$, and $\mathrm{SiO}_{2}$ (shown in Table 2) in an atomic ratio of $\mathrm{K}: \mathrm{Sn}: \mathrm{Si}$ as 2.06:1.00:3.16, which suggests a probable chemical formula of these particles as $\mathrm{K}_{2} \mathrm{SnSi}_{3} \mathrm{O}_{9}$. The minor $\mathrm{PbO}$ content may also suggest possible partial replacement of $\mathrm{Sn}$ with $\mathrm{Pb}$, written as $\mathrm{K}_{2} \mathrm{Sn}_{\mathrm{x}} \mathrm{Pb}_{(1-\mathrm{x})} \mathrm{Si}_{3} \mathrm{O}_{9}$. However, there were no signals corresponding to these crystals in XRD analysis and thus their formula was not fully confirmed [17].

Lighter particles with round edges in Figs. 2a and 3a contain much higher $\mathrm{PbO}$ content (68.36\%) compared to the matrix. The atomic ratio of $\mathrm{Pb}: \mathrm{Sn}: \mathrm{Si}$ is 1.00:0.35:0.73, which can be further speculated as $\mathrm{PbSn}_{0.32} \mathrm{Si}_{0.68} \mathrm{O}_{3}$. Such

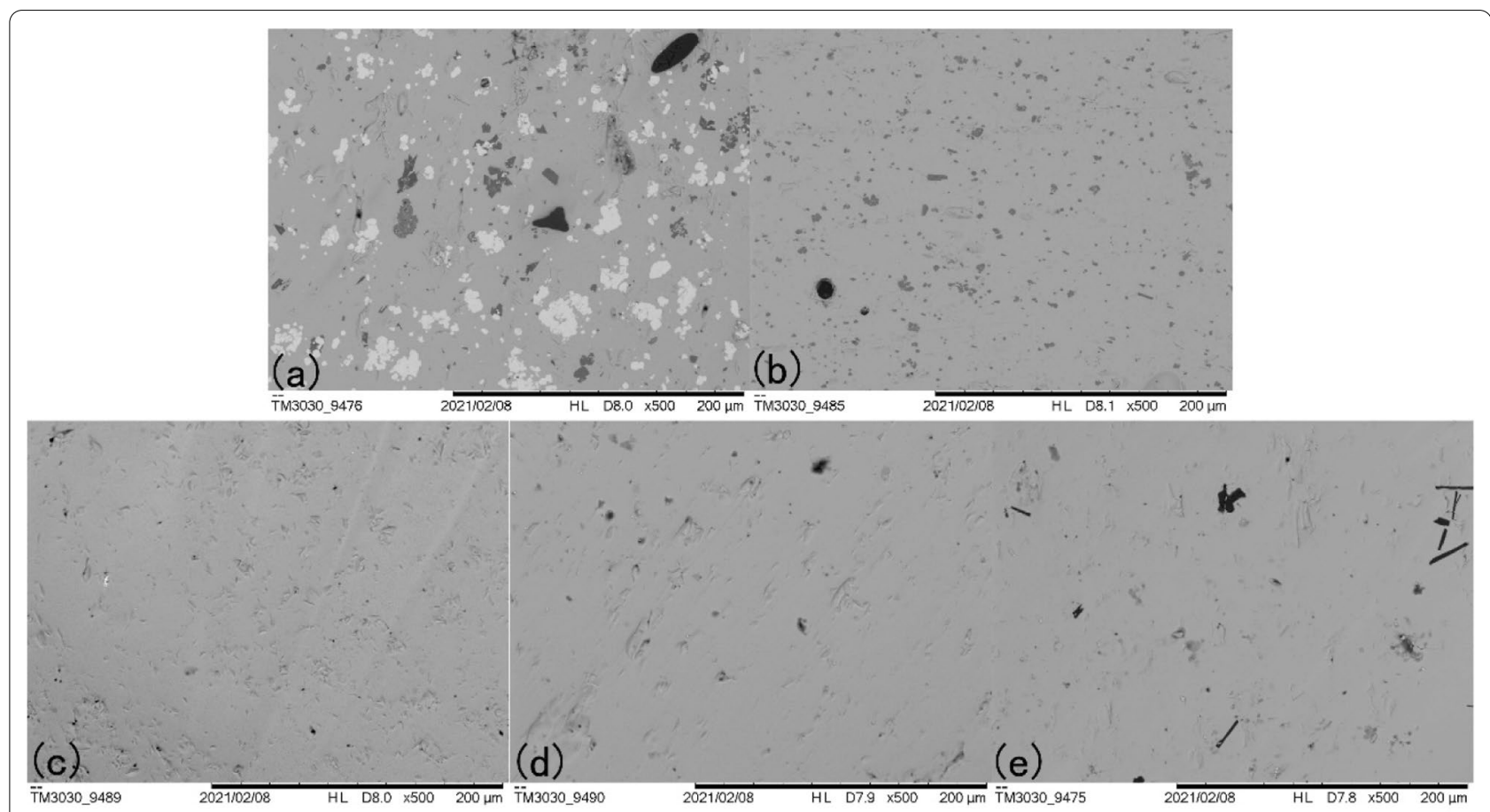

Fig. 2 BSE images of yellow (a), orange-red (b), blue (c), dark red (d), and light red beads (e) 


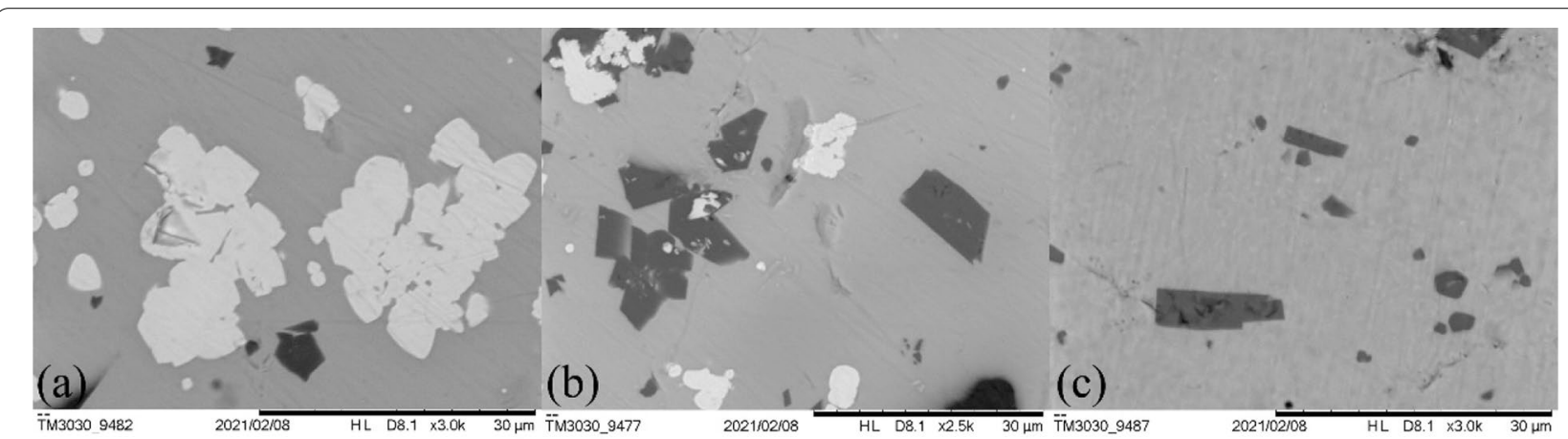

Fig. 3 BSE images of phases of interest: a Pb-Sn-Si phase (lighter particles) in a yellow bead, b K-Sn-Si phase (darker particles) in a yellow bead, $\mathbf{c}$ K-Sn-Si phase (dark particles) in an orange-red bead

Table 2 Chemical compositions of inclusive phases in the Nanhai I shipwreck beads

\begin{tabular}{lccccccc}
\hline & $\mathbf{P b O}$ & $\mathbf{S i O}_{\mathbf{2}}$ & $\mathbf{S n O}_{\mathbf{2}}$ & $\mathbf{K}_{\mathbf{2}} \mathbf{O}$ & $\mathbf{N a}_{\mathbf{2}} \mathbf{O}$ & $\mathbf{A l}_{\mathbf{2}} \mathbf{O}_{\mathbf{3}}$ & $\mathbf{C u}_{\mathbf{2}} \mathbf{O}$ \\
\hline Pb-Sn-Si phase in the yellow bead & 68.36 & 13.49 & 16.32 & 1.27 & 0.26 & 0.29 & - \\
K-Sn-Si phase in the yellow bead & 11.21 & 38.16 & 30.28 & 20.28 & - & 0.08 & - \\
Matrix of the yellow beads & 63.56 & 30.86 & 1.75 & 3.3 & 0.32 & - & - \\
K-Sn-Si phase in the orange-red bead & 12.69 & 42.57 & 23.88 & 19.63 & - & - & 0.22 \\
$\mathrm{Cu}_{2} \mathrm{O}$ particle in the orange-red bead & 20.12 & 6.62 & 4.72 & 1.13 & - & 0.24 \\
Matrix of the orange-red bead & 45.80 & 36.06 & 0.06 & 6.80 & 0.68 & 0.28 \\
\hline
\end{tabular}

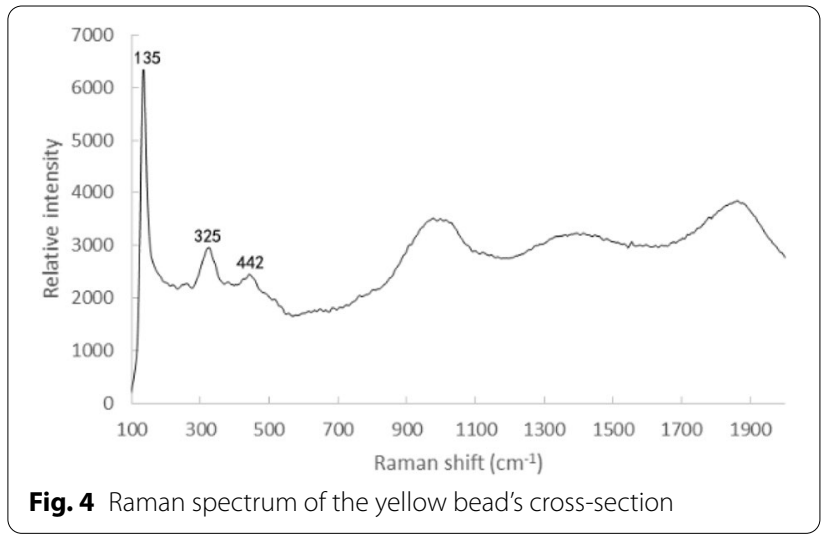

a result indicates the presence of lead tin yellow type II in the yellow beads, which can be either written in $\mathrm{PbSnO}_{3}$ by Rooksby [18] or $\mathrm{PbSn}_{\mathrm{x}} \mathrm{Si}_{1-\mathrm{x}} \mathrm{O}_{3}$ by Clark et al. [16]. Results from Raman spectroscopy shown in Fig. 4 further confirmed the presence of lead tin yellow type II. The spectrum of the yellow beads shows one sharp and pronounced peak at $135 \mathrm{~cm}^{-1}$ and two broad peaks at $325 \mathrm{~cm}^{-1}$ and $442 \mathrm{~cm}^{-1}$, exactly consistent with the spectrum of lead tin yellow type II, according to R.J.H. Clark's Raman study on the lead tin yellow pigments [16]. The XRD spectrum of the yellow beads powder is also provided in Fig. 5, showing the recognized phase as $\mathrm{PbSnO}_{3}$. Therefore, lead tin yellow type II does exist in these yellow coil beads. These irregular particles indicate that they were not formed by liquid phase separation during the firing process (in which case they would be more spherical). Considering their underdeveloped crystal form and clear XRD spectrum, these particles are cryptocrystalline.

According to Clark's study, lead tin yellow type II decomposes above $950{ }^{\circ} \mathrm{C}$ [16]. Hradil's study suggests that the higher calcination temperature is, the lighter the color of lead tin yellow type II will be. The pigment calcined at $850{ }^{\circ} \mathrm{C}$ has a reddish hue, while the pigment calcined at $900{ }^{\circ} \mathrm{C}$ is closer to the neutral yellow of yellow beads [13]. Therefore, to study the formation condition of lead tin yellow type II containing glass and confirm whether lead tin yellow type II was pre-synthesized and added to the glass formula or it can be directly formed from glass melts with $\mathrm{SnO}_{2}$ addition, we first synthesized lead tin yellow type II $\left(\mathrm{PbSn}_{\mathrm{x}} \mathrm{Si}_{(1-\mathrm{x})} \mathrm{O}_{3}, \mathrm{~Pb}: \mathrm{Sn}: \mathrm{Si}\right.$ feed ratio 2:1:1) and fired the glass according to the compositions tested.

The glass directly synthesized from $\mathrm{Pb}_{3} \mathrm{O}_{4}, \mathrm{~K}_{2} \mathrm{CO}_{3}$, $\mathrm{SiO}_{2}$ and $\mathrm{SnO}_{2}$ at $900^{\circ} \mathrm{C}$ is colorless when calcined for $0.5 \mathrm{~h}$ (shown in Fig. 6a), and it remained colorless 


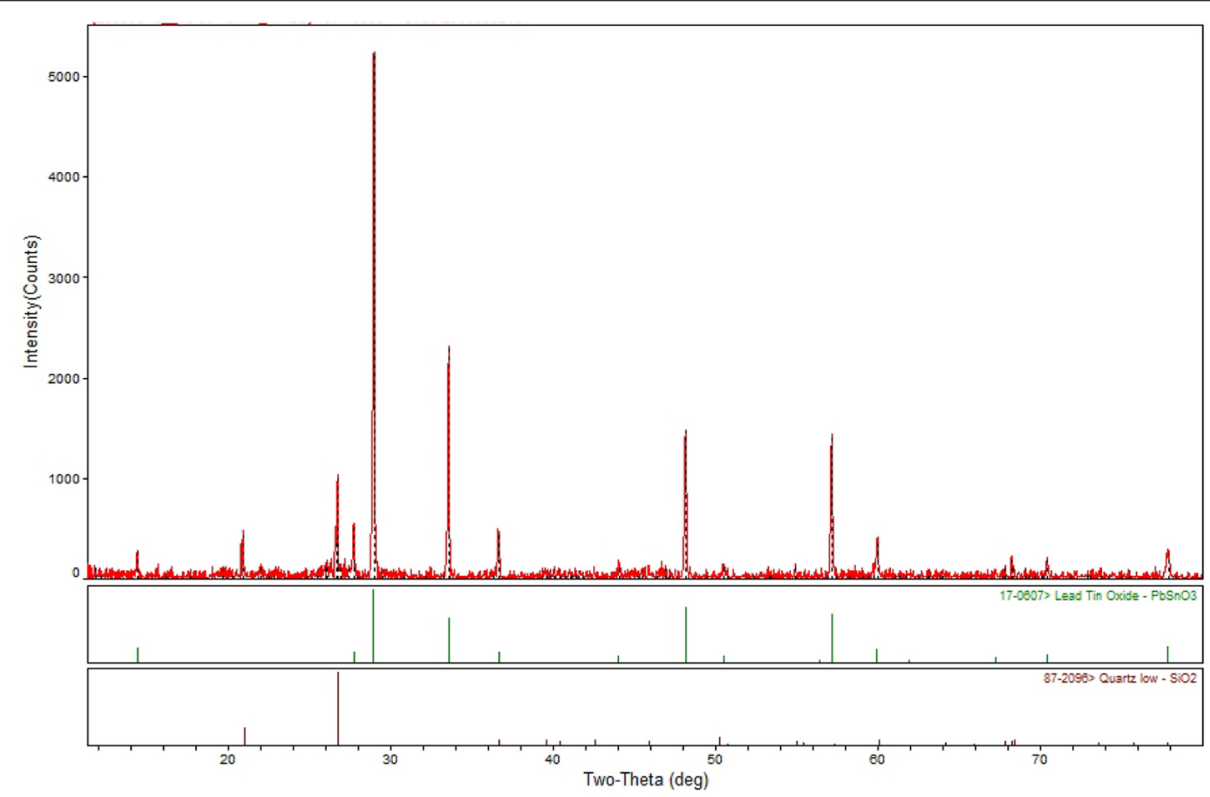

Fig. 5 XRD spectrum of the yellow bead powder

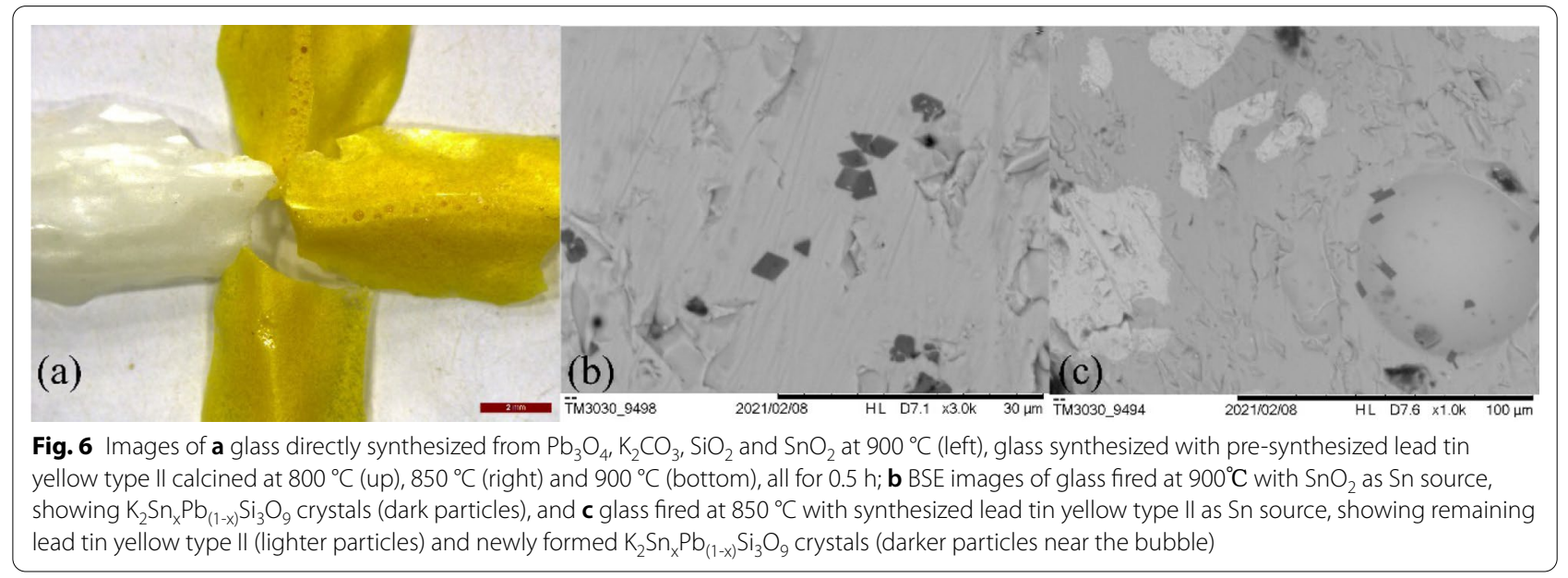

after being calcined for $5 \mathrm{~h} . \mathrm{K}_{2} \mathrm{Sn}_{\mathrm{x}} \mathrm{Pb}_{(1-\mathrm{x})} \mathrm{Si}_{3} \mathrm{O}_{9}$ crystals present in this colorless glass (shown in Fig. 6b). The glass synthesized from $\mathrm{Pb}_{3} \mathrm{O}_{4}, \mathrm{~K}_{2} \mathrm{CO}_{3}, \mathrm{SiO}_{2}$ and presynthesized lead tin yellow type II displays neutral yellow color despite the different calcining temperature at $800{ }^{\circ} \mathrm{C}, 850{ }^{\circ} \mathrm{C}$ and $900{ }^{\circ} \mathrm{C}$ (shown in Fig. 6a). $\mathrm{K}_{2} \mathrm{Sn}_{\mathrm{x}} \mathrm{Pb}_{(1-\mathrm{x})} \mathrm{Si}_{3} \mathrm{O}_{9}$ crystals present in the glass calcined at $850{ }^{\circ} \mathrm{C}$ and $900{ }^{\circ} \mathrm{C}$ (shown in Fig. 6c), which suggests lead tin yellow type II is not stable at such temperatures and partially transforms to $\mathrm{K}_{2} \mathrm{Sn}_{\mathrm{x}} \mathrm{Pb}_{(1-\mathrm{x})} \mathrm{Si}_{3} \mathrm{O}_{9}$ crystal. This crystalline phase serves as a signal of calcining temperature around or above $850{ }^{\circ} \mathrm{C}$. The synthesis of yellow glass succeeded only with the addition of pre-synthesized lead tin yellow type II, indicating that lead tin yellow type II was synthesized beforehand in the glass bead production while direct addition of $\mathrm{SnO}_{2}$ into the potash lead silicate glass only produce $\mathrm{K}_{2} \mathrm{Sn}_{\mathrm{x}} \mathrm{Pb}_{(1-\mathrm{x})} \mathrm{Si}_{3} \mathrm{O}_{9}$ crystals. Lead tin yellow type II was added as either colorant or both colorant and opacifier. The description "liuli beads of different colors" in $Z h u$ Fan Zhi corroborates the introduction of lead tin yellow type II as colorant. "Different colors" implies the bead makers had the information about what materials were needed to produce beads with certain colors and lead tin yellow type II was known to be a necessary 
raw material of yellow glass beads. The opacification is more likely to be unintentional or concomitant.

As the colorless glass synthesized from $\mathrm{Pb}_{3} \mathrm{O}_{4}, \mathrm{~K}_{2} \mathrm{CO}_{3}$, $\mathrm{SiO}_{2}$ and $\mathrm{SnO}_{2}$ at $900^{\circ} \mathrm{C}$ contains a considerable amount of presumed $\mathrm{K}_{2} \mathrm{Sn}_{\mathrm{x}} \mathrm{Pb}_{(1-\mathrm{x})} \mathrm{Si}_{3} \mathrm{O}_{9}$ crystals, it provided the opportunity to re-examine these crystals by XRD. The XRD peaks of the colorless glass match well with those presented in PDF\#27-0446 for $\mathrm{K}_{2} \mathrm{SnSi}_{3} \mathrm{O}_{9}$ and PDF\#411445 for cassiterite, though several differences regarding the $\mathrm{K}_{2} \mathrm{SnSi}_{3} \mathrm{O}_{9}$ have been observed. The diffraction angles

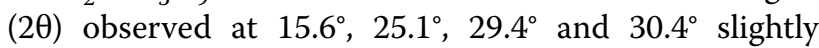
shift from $14.7^{\circ}, 23.3^{\circ}, 30.0^{\circ}$ and $30.7^{\circ}$ respectively. The deviations of the peaks indicate that $\mathrm{Pb}$ partly replaces $\mathrm{Sn}$ in the crystal as previously presumed. Therefore, it would be more accurate to describe these crystals as $\mathrm{K}_{2} \mathrm{Sn}_{\mathrm{x}} \mathrm{Pb}_{(1-\mathrm{x})} \mathrm{Si}_{3} \mathrm{O}_{9}$, though they are close to $\mathrm{K}_{2} \mathrm{SnSi}_{3} \mathrm{O}_{9}$ considering SEM results.

It is worth noticing that the lead tin yellow type II is not a typical colorant of Chinese tradition. Lead tin yellow type II does not occur naturally. And it has been used in both painting and glass coloring in the western world. The use of tin-based opacifiers in glass and pottery making dates back to early historical times [13], first in glass production in Egypt and the Near East in the mid-second millennium B.C. [5]. Glass beads with yellow trails dates back to the eighth-seventh century B.C. Sardis is the earliest occurrence of lead tin yellow type II that has been reported [19]. Lead tin yellow glass is produced in Europe during the first-second century B.C., and the gradual substitution of tin-based opacifiers, such as lead stannate yellow and tin oxide white, for antimony-based opacifier in glassmaking in Europe by fourth century A.D. makes the presence of lead tin yellow more frequent. The use of tin-based opacifiers spread from the eastern Mediterranean into northern and western Europe, and throughout the Roman and Byzantine Empires [10, 19]. This type of glass is popular at several sites during the fifth-seventh century around western Europe according to archaeological studies [10]. As a pigment, lead tin yellow is used in paintings from about the fourteenth-eighteenth century in Europe, and during the fifteenth-seventeenth century it has been used most frequently [11, 13, 20].

Some glass beads excavated in China have been reported to contain lead tin yellow type II, such as beads from Jiu-Zhi-Ling tomb site and Feng-Men-Ling tomb site, Hepu County, Guangxi [14], Shanpula tomb site, Lop County, Xinjiang [21], Da-Wang-Ku-Mu site, Xinhe County, Xinjiang [14] and Xiao Mausoleum, Xiangyang City, Shaanxi [15]. But considering their chemical compositions, these beads can hardly be regarded as samples of Chinese glass with lead tin yellow type II, for they are mostly identified as soda-lime glass of Central Asian or Western origins.

The beads excavated from Nanhai shipwreck I are so far the first and earliest evidence of lead tin yellow type II present in the Chinese glass system. However, there seems to be no clear evidence to trace the origin of lead tin yellow type II production. As the production of glass beads requires only simple equipment and can be done in small workshops, there would hardly be any identifiable remains. Although the chemical composition of the yellow beads belongs to the typical Chinese $\mathrm{K}_{2} \mathrm{O}-\mathrm{PbO}-\mathrm{SiO}_{2}$ glass system, its provenance cannot be fully confirmed by chemical composition alone. The lead isotope ratios of yellow Nanhai I shipwreck beads are shown in Table 3. The results correspond exactly with the lead isotope data of green glaze of ceramics from Cizao kiln also excavated from Nanhai I shipwreck [22]. It is very unlikely that the lead isotope ratios of the glass matrix are different from those of the lead tin yellow type II particles and their combined lead isotope ratios happen to be the same as those of green glaze from Cizao kiln. Therefore, both the glass matrix and the lead tin yellow type II were produced with exactly the same raw materials used by Cizao kiln, which further confirms the Chinese origin of the beads from Nanhai I shipwreck. Located in Jinjiang, Quanzhou, Fujian province, Cizao kiln was one of the manufacturing centers of export porcelains during Song and Yuan Dynasties [23]. Quanzhou port was also an important port from which China connected with Southeast Asia [1]. No evidence suggests that Cizao kiln produced glass, but the fact that ceramics from Cizao kiln and the yellow glass beads applied exactly the same raw materials indicating that the glass workshop was probably located in Quanzhou, the same district as Cizao kiln. It is now quite certain that lead tin yellow type II production technique was commanded by Chinese people during the Southern Song Dynasty. Yet there has been no lead tin yellow

Table 3 Lead isotope ratios of Nanhai I shipwreck beads and Cizao porcelain

\begin{tabular}{|c|c|c|c|c|c|}
\hline & ${ }^{207} \mathrm{~Pb} /{ }^{206} \mathrm{~Pb}$ & ${ }^{208} \mathrm{~Pb} /{ }^{206} \mathrm{~Pb}$ & ${ }^{206} \mathrm{~Pb} /{ }^{204} \mathrm{~Pb}$ & ${ }^{207} \mathrm{~Pb} /{ }^{204} \mathrm{~Pb}$ & ${ }^{208} \mathrm{~Pb} /{ }^{204} \mathrm{~Pb}$ \\
\hline $\begin{array}{l}\text { Green glaze of ceramics from Cizao } \\
\text { kiln }\left(\mathrm{PbO}-\mathrm{SiO}_{2}\right)\end{array}$ & 0.8619 & 2.1310 & 18.1406 & 15.6352 & 38.6580 \\
\hline Large yellow bead & 0.8623 & 2.1306 & 18.1231 & 15.6280 & 38.6127 \\
\hline Small yellow bead & 0.8618 & 2.1304 & 18.1423 & 15.6344 & 38.6502 \\
\hline
\end{tabular}


excavated or found in any other artifact of Chinese origin until it was used as glaze pigment on porcelain during Qing Dynasty $[24,25]$. Therefore, the lead tin yellow type II production technique was possibly introduced to China via the Maritime Silk Road, probably from Southeast Asia. Beads containing lead tin yellow before the Southern Song Dynasty have been excavated along Africa [26, 27], South Asia [28], and Southeast Asia [29, 30], and China had traded with the regions along the South China Sea Rim through the Maritime Silk Road for centuries. Therefore, the ancient Chinese glass makers might well be influenced by the Southeast Asian glass markers to apply lead tin yellow as colorant for yellow color. And the Southeast Asian glass makers are supposed to learn the techniques from the Western glass makers as lead tin yellow originated in the Mediterranean area [10]. The lead tin yellow beads excavated in Xinjiang, Guangxi and Shaanxi provinces indicate other possible transferring routes. But except one bead sample from Feng-MenLing, Guangxi, which is speculated to use local lead ore [14], there haven't been any more evidence of the combination of lead tin yellow and Chinese glass. As for the lead tin yellow bead possibly using Chinese lead ore, the lead content of it was below $7 \%$ and the bead was attributed to soda-lime glass [14], which has limited localization features. In addition, this bead sample from Guangxi dates back to the Han Dynasty, about 1000 years earlier than the Nanhai I shipwreck beads, and no similar products during this interval have been found. Thus, there seems to be very limited evidence to suggest that those early communication influenced the production of the yellow glass beads from the Nanhai I shipwreck. Therefore, taking the contemporaneity and frequent commerce into consideration, Southeast Asia was the most probable direct source of lead tin yellow techniques transferring into China and applied to the yellow beads from Nanhai I shipwreck. Furthermore, these glass beads seemed to be only for export purpose. No similar glass beads have been reported on Chinese mainland and lead tin yellow type II is not so appropriate a colorant in lead glass system compared with iron oxide. Thus, these yellow beads were more likely to be a combination of the coloring technique learning from Southeast Asia and the domestic glassmaking, and specifically made for overseas markets.

\section{Orange-red beads}

The remarkably high $\mathrm{Cu}_{2} \mathrm{O}$ content in EDS results indicates that the orange-red hue is probably caused by red cuprite. Raman spectrum of the orange-red bead has a sharp absorption at $213 \mathrm{~cm}^{-1}$, two weak broad absorptions at $422 \mathrm{~cm}^{-1}$ and $625 \mathrm{~cm}^{-1}$ and a strong broad absorption at around $3000 \mathrm{~cm}^{-1}$, which coincides with cuprite spectra from the RRUFF database.

Only one observable cuprite particle was found in orange-red beads observed (Fig. 7). The chemical analysis of the cuprite particle in an orange-red bead exhibits high cuprite content ( $67.18 \mathrm{w} \%)$. The presence of the cuprite particle indicates that cuprite was synthesized beforehand and introduced into the vitreous matrix as the colorant.

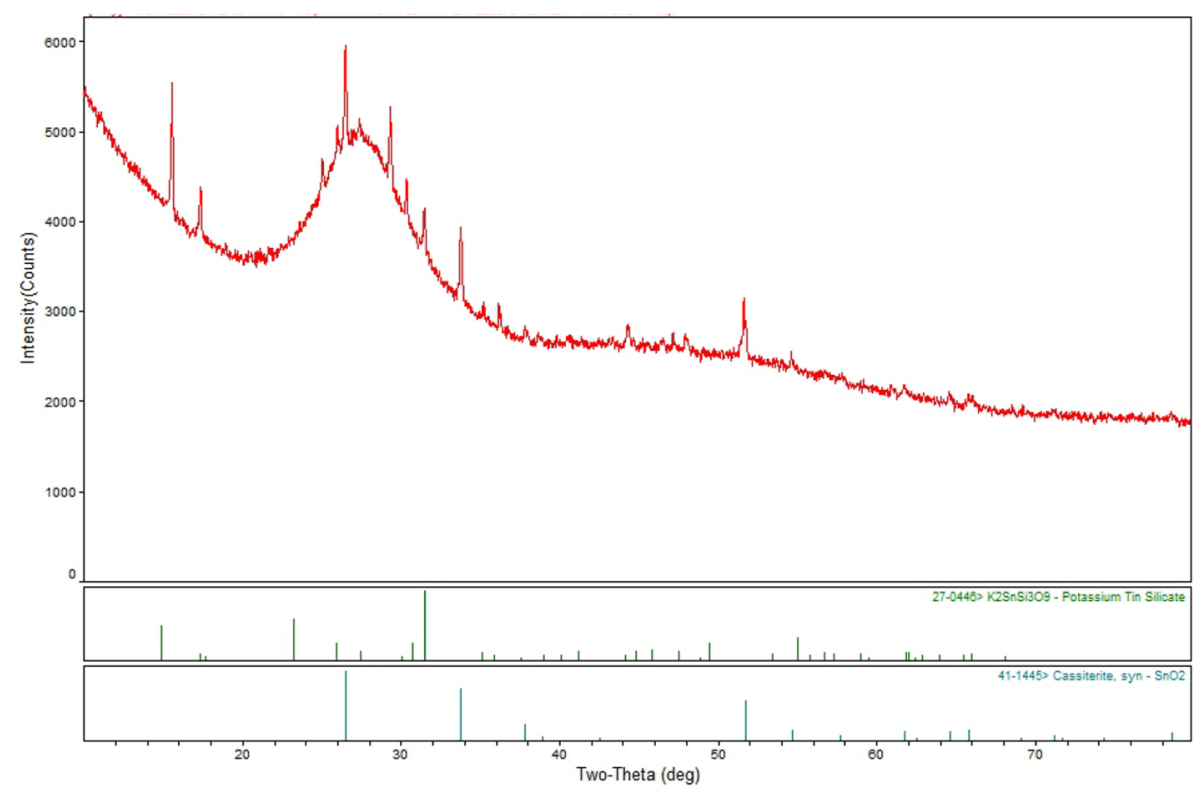

Fig. 7 XRD spectrum of the colorless glass (shown in Fig. 6a.) 
$\mathrm{K}_{2} \mathrm{Sn}_{\mathrm{x}} \mathrm{Pb}_{(1-\mathrm{x})} \mathrm{Si}_{3} \mathrm{O}_{9}$ crystals as previously discussed are also detected in orange-red beads (shown in Figs. 2b, 3c, and Table 1), which appear to be a characteristic phase of $\mathrm{SnO}_{2}$ containing $\mathrm{K}_{2} \mathrm{O}-\mathrm{PbO}-\mathrm{SiO}_{2}$ glass. However, there are no lead tin yellow particles present in the orange-red beads. Lower $\mathrm{PbO}$ and $\mathrm{SnO}_{2}$ contents (about $46 \%$ and $1 \%$ in the orange-red beads compared to about $58 \%$ and $4 \%$ in yellow beads) is a probable reason. And tin tends to form $\mathrm{K}_{2} \mathrm{Sn}_{\mathrm{x}} \mathrm{Pb}_{(1-\mathrm{x})} \mathrm{Si}_{3} \mathrm{O}_{9}$ instead of $\mathrm{PbSn}_{\mathrm{x}} \mathrm{Si}_{1-\mathrm{x}} \mathrm{O}_{3}$ particles in the $\mathrm{K}_{2} \mathrm{O}-\mathrm{PbO}-\mathrm{SiO}_{2}$ glass system. Additionally, considerable high content of $\mathrm{Cu}_{2} \mathrm{O}$ may affect the preservation of lead tin yellow type II during firing as well, even if Sn was introduced in the form of lead tin yellow type II. Thus, there're no lead tin yellow particles present (Figs. 8, 9).

\section{Blue beads}

$\mathrm{CuO}$ is responsible for the color of blue beads according to SEM results. Blue beads have $\mathrm{CaO}$ content (3.34\%) obviously higher than beads of other colors. As $\mathrm{CaO}$ is not a necessary substance in glass production, it was probably introduced by lime for unknown reason, and the possibility of plant ashes is excluded as no phosphorus has been detected and $\mathrm{MgO}$ content is low.

\section{Light red beads and dark red beads}

The SEM results indicate that $\mathrm{Cu}_{2} \mathrm{O}$ and $\mathrm{Fe}_{2} \mathrm{O}_{3}$ are responsible for the red color. And the different contents of $\mathrm{Cu}_{2} \mathrm{O}$ and $\mathrm{Fe}_{2} \mathrm{O}_{3}$ caused the distinction between light and dark red. The average $\mathrm{Cu}_{2} \mathrm{O}$ content of dark red
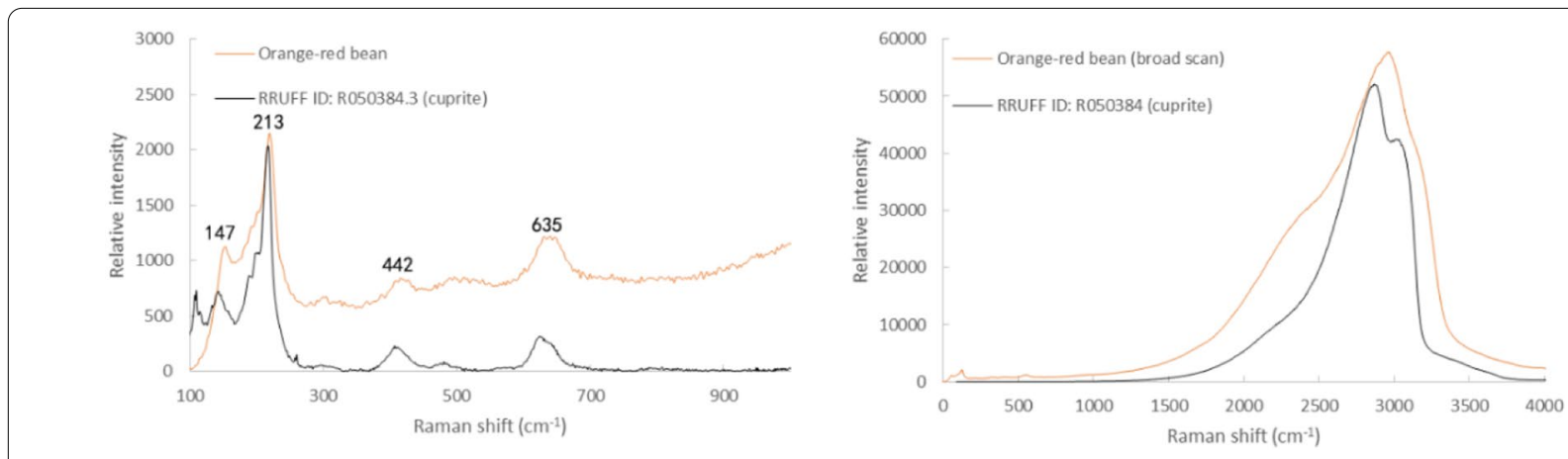

Fig. 8 Raman spectrum of the orange-red bead's cross-section

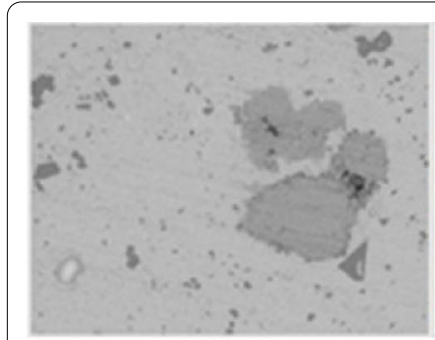

BSE

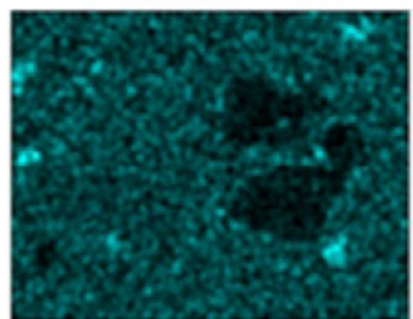

$\mathrm{K}-\mathrm{K} \alpha$

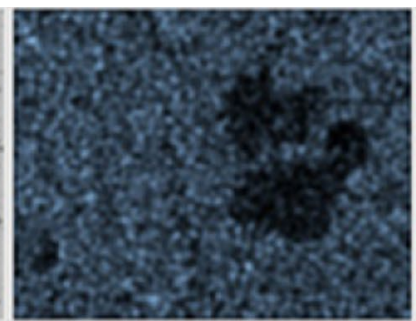

$\mathrm{O}-\mathrm{K} \alpha$

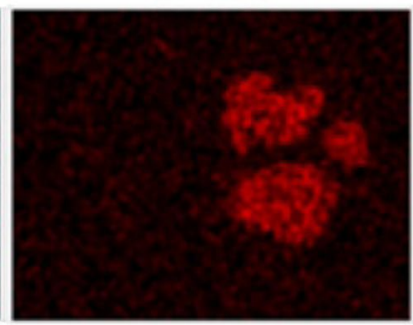

$\mathrm{Cu}-\mathrm{K} \alpha$

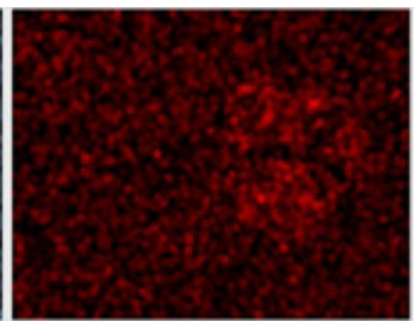

$\mathrm{Na}-\mathrm{K} \alpha$

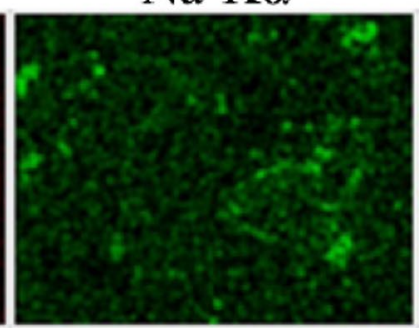

Sn-L $\alpha$

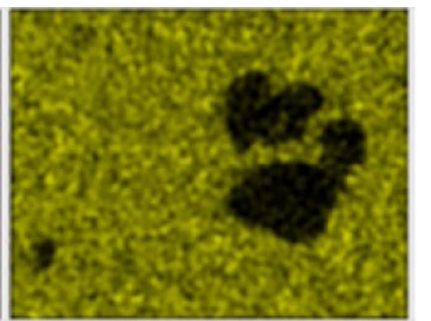

Si-K $\alpha$

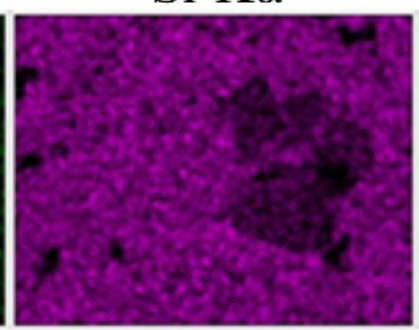

$\mathrm{Pb}-\mathrm{M} \alpha$

Fig. 9 BSE and elemental maps of the cuprite particle in an orange-red bead 
beads is $1.64 \mathrm{w} \%$, triple the $0.55 \mathrm{w} \% \mathrm{Cu}_{2} \mathrm{O}$ average content of light red beads, while the average $\mathrm{Fe}_{2} \mathrm{O}_{3}$ content is $1.42 \mathrm{w} \%$ for the dark one and $0.20 \mathrm{w} \%$ for the light one, a disparity of 7 times. In the dark red beads tested, $\mathrm{K}_{2} \mathrm{O}$ content is obviously lower than beads of other colors and $\mathrm{PbO}$ serves as the dominant fluxing agent [14].

It is noteworthy that transparent red glass, applying $\mathrm{Cu}_{2} \mathrm{O}$ as the colorant, is a characteristic of the Chinese glass system [1]. This kind of transparent red glass is commonly called "ruby red", and it further confirms the Chinese origin of the beads.

\section{Conclusion}

Coil beads excavated from Nanhai I shipwreck have been characterized by SEM, XRD and Raman spectroscopy. The beads tested all contain high $\mathrm{PbO}$ content (46$63 \mathrm{w} \%$ ), with $\mathrm{K}_{2} \mathrm{O}$ as a secondary fluxing agent, which corresponds well to $\mathrm{K}_{2} \mathrm{O}-\mathrm{PbO}-\mathrm{SiO}_{2}$ and $\mathrm{PbO}-\mathrm{SiO}_{2}$ glass systems of the Song Dynasty. The beads from Nanhai I shipwreck are divided into five groups by color: yellow, orange-red, blue, dark red and light red. Lead tin yellow type II, $\mathrm{Cu}_{2} \mathrm{O}$ and $\mathrm{CuO}$ are responsible for yellow, orange-red and blue respectively, while $\mathrm{Cu}_{2} \mathrm{O}$ and $\mathrm{Fe}_{2} \mathrm{O}_{3}$ together are responsible for the light and dark red with distinctions of contents. Lead tin yellow type II serves as both colorant and opacifier in yellow beads. According to Zhu Fan Zhi, lead tin yellow type II is more likely to be added as colorant intentionally. The presence of lead tin yellow type II and $\mathrm{K}_{2} \mathrm{Sn}_{\mathrm{x}} \mathrm{Pb}_{(1-\mathrm{x})} \mathrm{Si}_{3} \mathrm{O}_{9}$ particles helps to study the possible glass-making technology that lead tin yellow type II was synthesized beforehand and high temperature (around or above $850{ }^{\circ} \mathrm{C}$ ) is not conducive to keep the yellow color. This is so far the first clear evidence of the presence of lead tin yellow type II in the Chinese glass system. The lead isotope ratios of the yellow beads suggest the lead tin yellow type II was produced in Fujian Province, possibly in Quanzhou district. Furthermore, it is inferred that the coloring technique of lead tin yellow type II had a close connection to the glass making in the Southeast Asia and these glass beads seemed to be made specifically for overseas markets.

\section{Abbreviations \\ SEM-EDS: Scanning electron microscopy with energy dispersive spectrom- eter; MC-ICP-MS: Multi-collector inductively coupled plasma mass spec- trometry+; XRD: X-ray diffraction; BSE: Backscattered electron; PDF: Powder diffraction file.}

\section{Acknowledgements}

We thank Dr. ZHANG Ji from School of Archaeology and Museology, Peking University for helping conduct the lead isotope analysis.

\section{Authors' contributions}

All the experiments were designed and carried out by $C T$ and $Y Z$. The data were analyzed by $C T, Y Z$ and $\mathrm{KW}$. The sample was collected with the help of JS and $\mathrm{YC}$. The manuscript was written by $\mathrm{CT}$ and $\mathrm{YZ}$ and revised by $\mathrm{KW}$ and $\mathrm{DH}$. All authors read and approved the final manuscript.

Funding

Not applicable.

\section{Availability of data and materials}

The datasets analyzed during the current study are available from the corresponding author on reasonable request.

\section{Declarations}

Competing interests

There is no financial and non-financial competing interests.

\section{Author details}

${ }^{1}$ School of Archaeology and Museology, Peking University, 5 Yiheyuan Road, Beijing 100871, China. ${ }^{2}$ Underwater Cultural Heritage Protection Centre, State Administration of Cultural Heritages, Beijing, China. ${ }^{3}$ Guangdong Provincial Institute of Cultural Relics and Archaeology, Guangdong, China.

Received: 25 March 2021 Accepted: 20 May 2021

Published online: 29 May 2021

\section{References}

1. Francis P. Asia's maritime bead trade 300 B.C. to the present. Honolulu: University of Hawaii Press; 2002.

2. Posnansky M. Kilwa: an Islamic trading city on the east African coast. Int J Afr Hist Stud. 1978;11:496-502.

3. Carter AK. The production and exchange of glass and stone beads in southeast Asia from 500 BCE to the early second millennium CE : an assessment of the work of Peter Francis in light of recent research. Archaeol Res Asia. 2016;6:16-29.

4. Francis P. Glass beads in Malaya: a reassessment. J Malay Branch Roy Asiat Soc. 1991;64:97-118.

5. Then-Obłuska J, Dussubieux L. Glass bead trade in the early Roman and Mamluk Quseir ports - a view from the oriental institute museum assemblage. Archaeol Res Asia. 2016;6:81-103.

6. Carter AK, Beavan N. Glass Beads from the Jar Burials of the 15th to 17th centuries in the Cardamom mountains of Cambodia. BEADS I Soc Bead Res. 2014;26:9-21.

7. Gan F. Origin and evolution of ancient Chinese glass. In: Gan F, Brill RH, Tian S, editors. Ancient glass research along the silk road. Singapore: World Scientific Publishing Company; 2009. p. 1-40.

8. The archaeological team of Nanhai I. The 2014 excavation of Nanhai I shipwreck of the Song dynasty. Archaeology. 2016; 2016(12):56-83 (in Chinese).

9. Wood M. Glass beads from pre-European contact sub-Saharan Africa: Peter Francis's work revisited and updated. Archaeol Res Asia. 2016:6:65-80

10. Matin M. Tin-based opacifiers in archaeological glass and ceramic glazes: a review and new perspectives. Archaeol Anthropol Sci. 2019:11:1155-67.

11. Kühn H. Lead-tin yellow. In: Roy A, editor. Artists' Pigment: A handbook of their history and characteristics, vol. 2. Washington: National Gallery of Art; 1993. p. 83-112.

12. Burgio L, Clark RJH, Hark RR. Raman microscopy and X-ray fluorescence analysis of pigments on medieval and renaissance Italian manuscript cuttings. Proc Nat Acad Sci USA. 2010;107:5726-31.

13. Hradilova J, Bezdi P, Hradil D, Gr V. Microanalytical identification of Pb-SbSn yellow pigment in historical European paintings and its differentiation from lead tin and Naples yellows. J Cult Herit. 2007;8:377-86. 
14. Li Q, Liu S, Su B, Zhao H, Fu Q, Dong J. Characterization of some tincontained ancient glass beads found in China by means of SEM-EDS and Raman Spectroscopy. Microsc Res Tech. 2013;140:133-40.

15. Cheng $Q$, Zhang J. Scientific analysis and study of glass beads from Xiao Mausoleum of Emperor Wu of the Northern Zhou Dynasty. Archaeol cultur relics. 2011; 2011(1):107-112 (in Chinese).

16. Clark RJH, Cridland L, Kariuki BM, Harris KDM, Withnall R. Svnthesis, structural characterisation and Raman Spectroscopy of the inorganic pigments lead tin yellow types I and II and lead antimonate yellow: their identification on Medieval paintings and manuscripts. J Chem Soc Dalton Trans. 1995;16:2577-82.

17. Pertierra P, Salvadó MA, García-Granda S, Khainakov SA, García JR. Thermal behavior of $\mathrm{K} 2 \mathrm{MSi} 3 \mathrm{O} 9 . \mathrm{H} 2 \mathrm{O}$ with the structure of umbite $(\mathrm{M}=\mathrm{Sn})$ and kostylevite $(\mathrm{M}=\mathrm{Pb})$ minerals. Thermochim Acta. 2004;423:113-9.

18. Rooksby HP. A yellow cubic lead tin oxide opacifier in ancient glasses. Phys Chem Glasses. 1964;5:20-5.

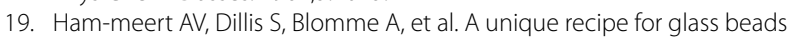
at Iron Age Sardis. J Archaeol Sci. 2019;108:104974.

20. Levstik MG, Mladenovič A, Kriznar A, Kramar S. A Raman microspectroscopy-based comparison of pigments applied in two gothic wall paintings in Slovenia. Periodico di Mineralogia. 2019;88:95-104.

21. Cheng Q, Guo J, Zhang H, Wang B. The colourful hub of the silk road: a study of glass beads excavated from two Shanpula tomb sites in the Khotan area of Xinjiang, China. Stud Conserv. 2014;59(suppl 1):S25-7.

22. Zhou Y, Wang K, Jin Y, Sun J, Cui Y, Hu D. Chemical and microstructural comparison of the export porcelain from five different kilns excavated from Nanhai I shipwreck. Ceram Int. 2019;45:12880-7.

23. Chen L. Quanzhou export ceramics on the Maritime silk road in the Song and Yuan Dynasties. In: Shanghai Maritime Museum of China, editor. Sea and people: the sea world of the Chinese. Shanghai: Shanghai Classics Publishing House; 2014. p. 12-21 (in Chinese).

24. Miao J, Yang B, Wang J. Studies on the Raman spectra of red, yellow and white pigments on the porcelain with Famille Rose Decoration produced in late Qing Dynasty. 2009 International Symposium on Ancient ceramics. 2009. p.441-446. (in Chinese).
25. Zhao L, Li H, Mou D, Wang J, Miao J. A study of Kangxi, Yongzheng Enamel Decorative Porcelains with non-destructive methods. 2009 International Symposium on Ancient ceramics. 2009. p.424-433. (in Chinese).

26. Then-Obłuska J, Dussubieux L. Beads for the nomads of late antiquity chemical characterisation of glass from the Blemmyan tumuli at Kalabsha, Nubia, mid-fourth century AD. Archaeometry. 2021. https://doi.org/ 10.1111 /arcm. 12680 (in press).

27. Prinsloo LC, Tournié A, Colomban P. A Raman spectroscopic study of glass trade beads excavated at Mapungubwe hill and K2, two archaeological sites in southern Africa, raises questions about the last occupation date of the hill. J Archaeol Sci. 2011;38:3264-77.

28. Pion C, Gratuze B. Indo-Pacific glass beads from the Indian subcontinent in early Merovingian graves (5th-6th century AD). Archaeol Res Asia. 2016;6:51-64

29. Saminpanya S, Bavornyospiwat N, Homklin S, Danyutthapolchai S, Bupparenoo P. Physical and chemical properties of the ancient glass beads from the highland log-coffin culture and the lowland areas, Thailand: considerations on their colors and technology. J Archaeol Sci Reports. 2016;8:366-80.

30. Saminpanya S, Saiyasombat C, Thammajak N, Samrong C, Footrakul S, Potisuppaiboon N, Sirisurawong E, Witchanantakul T, Rojviriya C. Shedding new light on ancient glass beads by synchrotron, SEM-EDS, and Raman spectroscopy techniques. Sci Rep. 2019;9:1-12.

\section{Publisher's Note}

Springer Nature remains neutral with regard to jurisdictional claims in published maps and institutional affiliations.

\section{Submit your manuscript to a SpringerOpen ${ }^{\circ}$ journal and benefit from:}

- Convenient online submission

- Rigorous peer review

- Open access: articles freely available online

- High visibility within the field

- Retaining the copyright to your article

Submit your next manuscript at $\boldsymbol{\nabla}$ springeropen.com 